\title{
Fair Copyright for Canada: Lessons for Online Social Movements from the First Canadian Facebook Uprising
}

\begin{abstract}
Despite their growing importance, the political effectiveness of social media remains understudied. Drawing on and updating resource mobilization theory and political process theory, this article considers how social media make "political engagement more probable," and the determinants of success for online social movements. It does so by examining the mainstreaming of the Canadian "user rights" copyright movement, focusing on the Fair Copyright for Canada Facebook page, created in December 2007. This decentralized, grassroots, social media-focused action - the first successful campaign of its kind in Canada and one of the first in the world - changed the terms of the Canadian copyright debate and legitimized Canadian user rights. As this case demonstrates, social media have changed the type and amount of resources needed to create and sustain social movements, creating openings for new groups and interests. Their success, however, remains dependent on the political context within which they operate.
\end{abstract}

\section{Blayne Haggart \\ Department of Political Science, Brock University}

Author's post-print peer-reviewed version

Published in:

Canadian Journal of Political Science 46:4 (December 2013): 841-861.

Acknowledgments: The author would like to thank Laura Macdonald, Sanjay Jeram, and three anonymous reviewers for their helpful comments. 


\section{Introduction}

The political effectiveness of social media continues to be hotly debated in the scholarly and popular literature (examples include Loader and Mercea, 2011; Calderaro and Kavada, 2013: 3; Bennett and Segerberg, 2011; Karpf, 2010; Shirky, 2011; Cohen and Raymond, 2011; Earl et al., 2010; Neumayer and Raffl, 2008; Gladwell, 2010). Social media - online sites that "emphasize the importance of user participation, openness and network effects" rather than providing information in a "uni-directional and static" manner (Bekkers, Moody and Edwards, 2011: 3) - are becoming ubiquitous tools of political action (Shirky, 2011: 1). An increasing number of dramatic real-world cases, including the ongoing Arab Spring revolutions, seem to provide evidence that social media can have significant policy and political effects (Rane and Salem, 2012). Their rising importance, however, has not been matched by sustained academic study of the extent to which social media use can influences policy change and political engagement (Calderaro and Kavada, 2013: 1; Shulman, 2009: 31; Jensen, Jorba and Anduiza, 2012: $1)^{1}$

This article argues that while the related approaches (Marwell and Oliver, 2008: 141) of resource mobilization and political process theories (RMT and PPT) were developed to explain traditional social movements (Tarrow, 2011; McCarthy and Zald, 1977; McAdam, 1982), they remain mostly useful for understanding the politics of protest in a digitally networked society (Garrett, 2006). Using RMT and PPT, and incorporating insights from the political communications literature provides a useful framework for considering how social media make "political engagement more 
probable," as well as the key question of what determines the success of such "digital social movements."

Applied to social media-enabled protests, RMT and PPT highlight how these new forms of communications have indeed "reconfigure[d] communicative power relations," by affecting the calculus of the resources needed for a social movement to succeed, as well as the relative importance of specific resources, and the declining importance of large organizations and mainstream-media exposure (Loader and Mercea, 2011: 763). Social media also allow for the creation of movements consisting of individuals who otherwise might never have met, including the reinforcement of nascent common identities. At the same time, digital social movements' endurance continues to rely on movement entrepreneurs' real-world institutional bases, as well as (as PPT reminds us) on the nature of the political system within which the movement's claims are made. While social media allow for those with previously unaddressed grievances the possibility to organize more efficiently, their success is contingent on the nature of the political system within which they are active, as PPT would suggest.

This article uses these approaches to examine the mainstreaming of the Canadian "user rights" movement related to copyright policy. It focuses on the December 2007 eruption of concern about the direction of Canadian copyright law, centred on the Fair Copyright for Canada (FCFC) Facebook page. Concerned that a copyright bill about to be tabled by the governing Conservative party would restrict Canadians' ability to use and access copyrighted digital works (such as MP3s and ebooks) at a time when digital technologies are blurring the line between "creators" and "users," Michael Geist, a University of Ottawa law professor and noted digital-copyright expert, created the FCFC 
Facebook page and turned a dry, technical subject into a front-page issue. Tens of thousands of individuals joined the page, and thousands directly lobbied the government to respect user rights. While the FCFC movement did not achieve some key goals in the subsequent legislation, namely permissive rules governing digital locks ${ }^{2}$ applied to digital works, its efforts directly led to the creation of new user rights and legitimized user rights in the Canadian copyright debate.

The FCFC movement was one of the first instances of "Facebook activism," or "online organizing" (Earl et al., 2010: 429). In subject matter and form it anticipated the January 18, 2012, "Internet Blackout," in which websites, most notably Wikipedia, went "dark" for a day to protest a U.S. copyright bill, the Stop Online Piracy Act (SOPA) that they claimed would fundamentally damage the Internet's open infrastructure. The result was an unprecedented online protest, in which millions of Americans contacted their elected representatives to complain about SOPA. Twenty-four hours later, faced with unanticipated public fury, the bill was effectively dead (Sell, 2013). It also preceded panEuropean protests in February 2012, in which $100,000^{3}$ took to the streets to demonstrate against an international intellectual property treaty, the Anti-Counterfeiting Trade Agreement (ACTA), that critics argued would have a negative effect on issues such as online privacy and freedom of speech (Amnesty International, 2012).

This article emerged from a larger study into North American copyright policy making (Haggart, forthcoming; Haggart 2011a). In addition to contemporaneous blog and media reports, it is based on elite, semi-structured interviews with key participants in this debate, including Michael Geist, activists, Canadian officials, and the chiefs of staff of two Conservative Industry ministers charged with crafting the legislation. Interviews 
were selected through a non-random snowball sampling process to ensure that all facets of Canadian copyright policy making were represented. ${ }^{4}$ All but one were conducted between January 18 and May 19, 2008, in the immediate aftermath of the launch of the FCFC webpage.

The first section of this article provides a brief overview of the literature on digital social movements and how these can be interpreted using RMT and PPT. The second offers an account, based primarily on interviews with key players, of the emergence and effects of the 2007 FCFC protest. The third section analyzes the effects of the protests. The paper concludes with some comments about what this case tells us about the future potential of online protests.

\section{A. Theorizing the political effects of social media}

Social movements are "collective challenges, based on common purposes and social solidarities, in sustained interaction with elites, opponents and authorities" (Tarrow, 2011: 9). While there remains a dispute over the exact mechanisms and degree to which they influence political life and social movements, social media are characterized by three features (boyd and Ellison, 2009). They allow users to: construct a profile potentially available to everyone on the Web; build a network of connections to other users; and browse these own connections, effectively linking overlapping networks (Faris, 2008: 2-3). Social movements can engage in several types of online activism. Earl et al. (2010: 429) offer a useful typology, distinguishing among four specific types:

- "brochure-ware" activism (information dissemination);

- online facilitation of offline activism (information provision for offline activities); 
- online participation (for example, online petitions, email campaigns and distributed denial of service attacks); and

- online organizing (movements that are fully organized online).

Of the four, online organizing - which describes the FCFC protests - has been the least studied in proportion to its actual prevalence (2010: 440). It represents a key battleground for the debate over the political effectiveness of social media. In a way, it represents the "purest" form of online activism: it is neither a mere a complement to "offline" activities (as are the first two categories), nor a strategy (as is the third). Rather, it is a form of organization that was nonexistent before the rise of the Internet.

\section{Resource mobilization and political context in an online world}

Resource mobilization theory and political process theory (McAdam et al., 1996) is a useful way to organize the disparate literature on social movements and new information and communication technology (ICT) (Garrett, 2006: 203). RMT and PPT address the conditions influencing the creation and success of social movements. Social insurgency is a function of the movement's degree of organizational readiness. Its success also depends on a "conducive political environment" (the subject of PPT), which "only affords the aggrieved population the opportunity for successful insurgent action. It is the resources of the minority community [RMT's purview] that enable insurgent groups to exploit these opportunities" (McAdam, 1982: 40, 43).

Digital technologies, and social media in particular, have changed many parts (though not all) of the terrain on which social movements are formed and developed. Drawing on RMT, Garrett notes that ICT can influence participation in social movements in three ways: first, by reducing the cost of participation (on both the supply and demand 
side); second, by promoting the existence of a collective identity; and third, by creating a community (2006: 204; see also Loader, 2008: 1920, 1923; Calderaro and Kavada, 2013: 2; McAdam, 1982: 48-51).

On the first point, social media and ICT reduce mobilization costs, even over great differences. Mobilization in a world in which everyone is online, and in which everyone belongs to highly visible overlapping personal and professional networks, no longer requires "recruiting blocs of people who are already highly organized and participants" in social movements (McAdam, 1982: 45). Nor are existing organizations necessarily "the primary source of resources facilitating movement emergence," (McAdam, 1982: 48). Contacting and activating potential supporters used to require relatively large investments (such as in direct-mail campaigns) that could best be undertaken by large, centralized organizations. When one billion people are on Facebook, social movements can, in a sense, "free ride" on these already-established webs of connections.

On the second point, by simplifying and speeding up communication across great distances, ICTs and social media allow for the creation of shared identities (and communities) that would not have been otherwise possible. With respect to framing "strategic attempts to craft, disseminate and contest the language and narratives used to describe a movement" (Garrett, 2006: 204) - reaching potential supporters and turning latent interests into identities (as people realize they are not alone with their concerns) becomes easier in a networked society. It can also lead to more rapid creation and diffusion of social movements, as well as quicker cycles of mobilization and protest, including the waxing and waning of protest movements (Garrett, 2006: 206-207). 
The primary debate in the literature on social movements has been on the third point, which revolves around the long-held assumption that "strong" social movements require face-to-face interactions. In a classic text Tarrow argues: "Although it is individuals who decide whether or not to take up collective action, it is in their face-toface groups, their social networks, and the connective structures between them that it is most often activated and sustained" (2011: 22), a view echoed by Putnam (2000). Critics, including Gladwell (2010), Tilly (2003: 23) and Diani (2000: 3397), have argued that the "weak ties" created by virtual interactions are not sufficient to create cohesive movements capable of political change. That said, empirical studies increasingly suggest that weak ties can lead (and have led) to social change (Garrett, 2006: 206; Carty, 2008; Harlow and Harp, 2012; Margetts et al., 2009). This is in line with Veenhof et al.'s finding that the Internet is transforming, not destroying community-making: "More and more, community is extending beyond face-to-face interaction with small groups of neighbours" (2008: 23).

The dismissal of people who merely "like" a Facebook page stems from a fundamental misunderstanding of their role in a social movement. Using the language of traditional social-movement studies, they are "adherents," who comprise the universe of potential activists for a movement (McCarthy and Zald, 1977: 1221). They should not be confused with "constituents," those who actively support the movement/organization with resources such as time or money. The main difference between online and traditional social movements is that it is now much easier to identify the universe of potential activists. "Likes" also serve as a signal to activists and decision makers about the strength of this latent support, as well as a resource for those wishing to convince the 
"most courageous members of these groups" to take more direct action (Tarrow, 2011:

23). Furthermore, rendering visible the universe of potential adherents creates a new resource, signaling to observers the legitimacy of a movement's activists and leaders, demonstrating "the movements' power to potential converts, opponents, and third parties" (Oostveen, 2010: 795-6; see also Badouard and Monnoyer-Smith, 2013: 140).

One should not overstate the extent to which digital technologies have changed the dynamics of starting or maintaining a movement. People, not technologies, form social movements. Leaders, or "movement entrepreneurs," continue to play a role in channelling passions and "selecting forms of collective action" (Tarrow, 2011: 29). ${ }^{4}$ Similarly, digital technologies have reduced, not eliminated, organizing costs, though they have affected the type and quantity necessary for a successful movement. Compared with traditional "offline" forms of organization, social media and the Internet make it easier for disparate individuals to connect, develop a common frame, or identity, share information and coordinate activities. Furthermore, in a highly networked world replete with specialized alternative news sources (including blogs and Twitter), mainstreammedia coverage is no longer a do-or-die barrier for social movements looking to inform and attract followers or to exert pressure on democratic governments (Garrett, 2006: 213).

However, absent sufficient material and institutionalized support (access to "legitimacy, money, facilities and labour" (McCarthy and Zald, 1977: 1220)), onlineorganized movements or protests will tend to burn brightly then fade away. Their continued relevance will depend on the extent to which these movements are rooted in offline institutions and receive ongoing material support. Among other supports, the 
FCFC online user-rights movement is sustained to a great degree by University of Ottawa professor Michael Geist, who has been able to leverage his position as a respected tenured academic to research and promote user rights before and after the initial FCFC protest.

Nor does the advent of social media change necessarily change the "opportunity structures" (McAdam et al., 1996) faced by a social movement. As political process theory reminds us, "whether or not endowed with resources and functioning organizational structures, social movements are influenced by the surrounding political climate" (Ruggiero and Montagna, 2008: 5). While social media and the Internet generally provide "a new opportunity structure for individual citizens — as well as ad hoc and loosely coupled small groups of citizens - to raise their voices and to express specific demands in order to influence the political agenda" (Bekkers et al., 2011: 1), online activists usually will succeed or fail depending on their ability to exert influence within existing institutions. Assessing the reasons, or potential, for the success/failure of a social media-linked campaign requires examining the direct effects of these technologies on the movement/protest and the political-institutional context within which the protest occurs.

\section{Defining change}

As Calderaro and Kavada note, "social movement research has traditionally paid more attention to the process rather than the outcomes of mobilizations" (2013: 1). Social movement-driven change can be measured in several ways (Gamson, 1990), two of which are particularly relevant here. A social movement can change the terms of the debate to favour its positions; it can also lead to the enactment of specific policies. Change in this article is defined in terms of the government's legislative position on user 
rights and response to the user-rights movement. It follows the debate's development from the introduction of a first copyright bill in 2005 under a minority Liberal government, through two unsuccessful attempts to pass a bill under minority Conservative governments in 2008 and 2010, and finally to its successful passage in 2012 under a majority Conservative government. User rights are those that have as their primary concern the ability of individuals or other groups to access, manipulate and share copyrighted works. Much of the Canadian user-rights debate focused on whether legal protection would be extended to digital locks, or technological protection measures (TPMs). These are encryptions applied to digital media that control how they may be used or accessed, and can often have significant implications beyond preventing copying. TPM protected books purchased from Amazon.com, for example, can only be used on Amazon's Kindle or Kindle app, effectively locking a user to Amazon's proprietary platform. Making it illegal to break a digital lock is a form of "paracopyright"protecting the lock rather than the underlying work - that potentially overrides existing user rights under copyright law and impairs the functioning of other laws, including those related to competition policy (de Beer, 2005).

While it is usually difficult to attribute a political outcome to one cause, the Canadian copyright debate under discussion here represents an ideal case to test these propositions. FCFC emerged in the middle of a process that had begun with consultations in 2001 (discussed below) and had already seen one proposed copyright bill (in 2005) that did not directly address user rights. A new interest group in Canadian copyright policy-making, it was the only one directly focused on copyright limitations that would favour individuals. 


\section{B. Copyright in Canada: Shifting ground}

Copyright is a limited form of intellectual-property protection applied to creative works, such as books, music, motion pictures and computer software. Crafting copyright law involves a difficult balancing act among creators, copyright owners (who are often not the actual creators), distributors (such as motion picture and music companies) and "users" (such as research libraries and individuals). The global trend in copyright law, particularly since the mid-1970s, has favoured "protection" interests, such as the content industries (including the music, film and publishing industries), seeking ever-stronger copyright protection over "dissemination" interests, including user groups such as libraries, telecommunications companies and individuals (Doern and Sharaput, 2000). ${ }^{6}$

The previous major Canadian copyright reform process, which ended in 1997, did not attract much interest outside of what one Department of Canadian Heritage official called the "corporate interests" - those large entities, such as the content industries, artists' unions and collecting societies, libraries and universities (Personal interview, February 7, 2008). The spread of digital communications technologies has brought individuals directly into conflict with existing copyright laws. No longer passive content consumers, individuals with access to a computer and the Internet can now reproduce and distribute any digital creative work as easily as a multi-billion-dollar Hollywood studio.

Canadians' interest in copyright had been building for years before the 2007 copyright protests. In 2001, hundreds of Canadians participated in public copyright consultations designed in part to adjust Canadian copyright law for the digital age (Bannerman, 2006). Canadians were worried that the Canadian law would mirror the US 1998 Digital Millennium Copyright Act (DMCA), which had been criticized for taking a 
non-user-friendly approach to the United States' treaty obligations (Haggart, 2011). This fear was not unjustified: the United States, representing its copyright industries (such as the music and motion picture industries), has been the main proponent of stronger copyright protection, including strong digital-lock protection, in Canada and around the world.

The first attempt to reform Canada's copyright laws, June 2005's Bill C-60, An Act to Modernize the Copyright Act, did not contain any specific new user rights, although it took a "minimalist" approach to the question of digital locks. It would have made it illegal to break a digital lock only if it were done for the purposes of infringing the underlying copyright. By not creating legal protections for the digital lock itself, as was done in the U.S. DMCA, it avoided creating any new rights that would have effectively vested control over a copyrighted work in whoever controlled the digital lock in question.

The bill, however, was a victim of the September 2005 fall of the minority Liberal government. When its successor, Steven Harper's minority Conservative government placed An Act to Amend the Copyright Act on the Order Paper on December 10, 2007 (that is, announcing that they would soon be tabling the bill), observers expected that this new bill would be much closer to the maximalist, anti-user US DMCA than the Liberals' C-60 had been, specifically that it would provide strong legal protection for digital locks as in the DMCA.

\section{The first Canadian Facebook "uprising"}

By the mid-2000s, Canadians interested in following copyright issues could draw on several specialized online sources, including a small but active community of 
Canadian bloggers. These include University of Ottawa Law Professor and Canada

Research Chair in Internet and E-Commerce Law Michael Geist (www.michaelgeist.ca), Ottawa copyright lawyer Howard Knopf (excesscopyright.blogspot.com), and software developer Russell McOrmond (ww.digital-copyright.ca). Geist undoubtedly has been the central movement entrepreneur in the user-rights debate, using his legitimacy, expertise and institutional base at the University of Ottawa to address digital-copyright issues, including consulting with government officials, tracking digital-copyright issues through Access to Information requests, writing extensively for his own blog and a weekly column in the Toronto Star and editing two edited volumes on Canadian digital-copyright reform.

Despite signs that copyright was on the verge of becoming a mainstream issue, what happened next caught everyone in Ottawa off guard. Geist managed to make public concern with the new legislation visible though the innovative use of new media, specifically Facebook. On Saturday, December 1, 2007, Geist set up a Facebook page, Fair Copyright for Canada:

to help ensure that the government hears from concerned Canadians. It features news about the bill, tips on making the public voice heard and updates on local events. With regular postings and links to other content, it also provides a central spot for people to learn more about Canadian

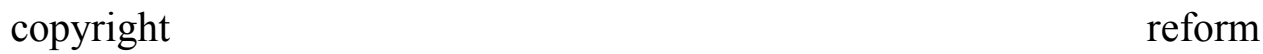
(http://www.facebook.com/group.php?gid=6315846683).

As this quote suggests, the basic initial demand was for the government to engage in consultations with Canadians and address the topic of user rights, which would help to 
ensure that copyright law not be strengthened in a way that impedes Canadians' access to knowledge, culture and information, such as through strong protection for digital locks beyond that proposed by the Liberals' Bill C-60. The FCFC Facebook group demonstrated the power of social-networking media to educate and help people organize themselves loosely in a way that is politically effective. Surprising even Geist, the group hit 11,000 members in just a week. According to Geist:

It would be disingenuous for me to say that I thought it would grow as quickly as it did and have the immediate impact that I think that it had, but I certainly was on the view that we could get large numbers of people - perhaps not quite as large as we thought - but large numbers of people, relatively quickly [by using] Facebook as a tool (Personal interview, May 14, 2008).

The page's call to action led "to hundreds of letters and phone calls to [Industry] Minister [Jim] Prentice [the bill's sponsor], Prime Minister Harper and MPs from every political party. It has fostered a robust conversation among many Canadians about balanced copyright" (Geist, 2007). Geist had surprisingly little to do with the actual organization of direct protests. While he solicited some individuals to set up their own "Fair Copyright For Canada" chapters across the country, once established - some 23 by late June 2008 (Geist, 2008) - they largely made decisions for themselves, including engaging in direct lobbying.

The government took notice. According to Michele Austin, Chief of Staff to Maxime Bernier (Prentice's predecessor at Industry), individual MPs were "panicked” by this outpouring of concern, which often involved face-to-face meetings between constituents and their MPs. These meetings, on an issue they knew little about threw 
backbenchers into disarray and confusion (Personal interview, April 30, 2008). In the following months, other groups would host meetups and strategy sessions. Rob Hyndman, a technology lawyer who helped to organize the Toronto chapter, estimated in April 2008 that his chapter had over 500 members, with between 20 and 25 involved in a face-to-face meetup in late February 2008, over two months after the initial FCFC excitement (Personal interview, April 22, 2008). Particularly memorable was the direct action was undertaken by Kempton Lam, a Calgary-based blogger and documentary filmmaker (Personal interview, April 16, 2008). A newcomer to copyright policy, he used the FCFC Calgary Chapter Facebook page to organize an impromptu demonstration/attempted meeting with Industry Minister Jim Prentice during Prentice's Saturday, December 8, 2007, Christmas Open House in his Calgary North riding office. Between 40 and 60 people showed up at Prentice's riding office to talk with the minister. The meeting got coverage on the local news, thanks to Lam having alerted them, as well as coverage on international blogs such as the copyright-critical website Boing Boing.

The unexpected protests and face-to-face meetings with government MPs, unnerved the government, which at the time did not control a majority in Parliament. Furthermore, according to Austin, Industry Minister Prentice was also facing resistance around the Cabinet table from ministers concerned that the bill did not include any exceptions for everyday activities like copying music you owned to your iPod (Personal interview, April 30, 2008). ${ }^{7}$ The minority Parliament itself was a problem: in a couple of months the government would be facing a contentious vote on the future of the war in Afghanistan and faced a Liberal opposition of (then-)unknown resolve. Faced with these complications, the government delayed introducing the bill - C-61, an Act to Amend the 
Copyright Act - until June 2008. By June 12, 2008, when the Conservatives finally introduced C-61, FCFC membership had grown to 41,670 (Delacourt, 2008).

Fair Copyright for Canada was directly responsible for this delay. Prentice's chief of staff, Jean-Sébastien Rioux, argues that the bill was the victim of a "communications problem":

The original cause for the December pause was recognizing, realizing that because of the Facebook stuff and because of the misinformation, a lot of people [MPs] were nervous. Some of the caucus MPs [were] like, 'What's going on? Is this true? Is that true?' And then you realize, 'Oh my gosh, we've got to make sure this is explained better because you're touching a lot of nerves there' (Personal interview, February 26, 2009).

For Austin, the bill represented a political problem. One of her concerns was that the bill affected

our core voters. Single men under the age of 30 vote conservative; they were affected. We are desperately trying to get the mothers of the 13-year-old boys to vote Conservative; they would be affected. ... And, at least to PMO's credit, they figured that out. They went, 'Holy crap, these are dangerous individuals, statistically and possibly in a voting bloc, we should figure out how to deal with this' (Personal interview, April 30, 2008).

This delay meant the government was unable to move the bill through Parliament before the government fell three months later, and was similarly unsuccessful in the three-year, Conservative-led minority Parliament elected in September 2008. Copyright's politicization meant that, in the words of NDP MP Charlie Angus, "you mention 
copyright on Parliament Hill and pretty much all the politicians run to their respective bunkers and put their helmets on" (cited in Smith, 2008: 23). The Conservatives would be unable to pass a copyright bill until 2012, on the strength of the majority mandate it won in May 2011.

\section{Digital protests, mixed results}

As Austin and Rioux's comments indicate, the Conservative government recognized that the concerns enunciated by FCFC and other groups represented a political problem that had to be addressed. The effectiveness of the FCFC protests can be evaluated by examining outcomes in terms of government reaction to its main demands public consultations and user-friendly digital-lock rules (see below) - and whether user rights, previously severely underrepresented in the Canadian copyright policy-making process, rose in legitimacy. The protests, while not completely successful, realized several significant victories.

Regarding public hearings, the protests were an unqualified success. All of the civil servants and Conservative officials interviewed through 2008 and early 2009 expressed the opinion that the 2001 hearings had sufficiently covered the issue (Gratton and Mirella, personal interviews, February 7, 2008; Austin, April 30, 2008; Rioux, personal interview, February 26, 2009). That the government held widespread public copyright consultations in the summer of 2009 can only be seen as a triumph for those associated with the FCFC movement. The hearings themselves reinforced the impression of extensive, near-overwhelming support for greater user rights from individuals, new artists groups, public-interest groups and tech companies, all of whom were relatively new to the copyright debate. Some 6,642 of the 8,300 -plus submissions to the 
government's 2009 copyright consultations were critical of increased protection for digital locks (Geist 2010a). Comparing form letters from both sides of the debate, 5,025 form letters were sent in through the pro-user-rights Canadian Coalition for Electronic Rights. In contrast only 25 people submitted form letters from the recording and publishing industries (Geist, 2010b).

On the content of the Conservative bills, the FCFC's record was more mixed. Between June 2008 and September 2011, the government introduced three substantively similar bills. ${ }^{8}$ Each fell short of being completely friendly to user interests. The modified June 2008 bill and its subsequent iterations included new user rights such as for "format shifting" and time shifting of legally obtained works, and a right to create noncommercial content from existing content (Lithwick and Thibodeau, 2011). However, all the bills provided strong protection for digital locks, making it illegal not only to break these locks in most cases, but also making it illegal to traffic in devices that could break these locks. As a result, even where people are legally entitled to break a digital lock, they are unable legally to obtain the means to do so. Furthermore, the presence of a digital lock on a work overrides these new user rights to format- and time-shift. This outcome reflects the government's opinion, as expressed by Prentice's chief of staff, that the problem with the bill circa December 2007 was with the communication strategy, not the actual policy (Rioux, personal interview, February 26, 2009). The decision to side with the United States was the result of a directive from the Prime Minister's Office to, in Austin's words, to “move quickly, satisfy the United States. ... 'We don't care what you do, as long as the US is satisfied'." However, the fact that the previous Liberal government introduced a bill that did not satisfy the Americans demonstrates that the 
PMO's decision to follow the US lead was a choice, not a necessity. That the final bill maintained the strong digital lock protection while offering concessions to this new user lobby effectively reconciled these two constituencies.

The mere inclusion of any user rights in the bill represented a victory for the FCFC movement. While there had been precedents, notably a Supreme Court ruling in 2004 (CCH Canadian Ltd. V. Law Society of Upper Canada), the FCFC movement placed user rights squarely on the Canadian political agenda, to the extent that the government saw it as necessary to at least pay lip service to them in pursuit of their final objective. This previously neglected dimension of copyright came to be the dominant frame through which the copyright bills were discussed (Geist, 2012). The next copyright debate will have to take user rights into account. ${ }^{9}$

While FCFC was the most visible group protesting the legislation, they were not alone. On the business side, the Business Coalition for Balanced Copyright, representing business "user" interests such as Google, Rogers and the Retail Council of Canada, emerged in early 2008 (after FCFC) (Business Coalition for Balanced Copyright 2008). Other critics included the Canadian Library Association, Canadian Privacy Commissioners, the Canadian Software Innovation Alliance (representing Canadian open-source software developers), the Canadian Association of University Teachers, and the Songwriters Association of Canada (Haggart, 2011a: 292), as well as the Consumers Council of Canada, the Canadian Council for Electronic Rights, and creators groups such as Appropriation Art, and the Canadian Music Creators Coalition (Baird, 2009: 21).

The central role of FCFC can be seen in how the Conservatives refined their approach to copyright reform after December 2007. Thanks to the pressure from the 
protests that began with FCFC in December 2007 the government was forced to respond directly to critics' contention that the bill was "Born in the USA" (Geist, 2008a) by insisting it was "made in Canada" (Industry Canada 2008), indicating that the government did not fully control the copyright narrative. Exceptions included in the legislation, such as the YouTube mashup exception and format shifting, are of direct interest to consumers and were not in the initial legislation. Furthermore, the protests both sparked the widespread discontent and caused the government to delay the legislation, due to concerns within government, not with its content, but with how the bill was being communicated to Canadians and to the Conservative caucus (Rioux, February 26, 2009). Even the delay of C-61 "was a victory of sorts for opponents," demonstrating that copyright had been politicized (Smith, 2010: 27).

\section{Explaining outcomes}

The FCFC Facebook protest page was a textbook example of "online organizing." Geist's original webpage sparked an unexpected firestorm of protest and debate. While the eventual Conservative bill touched on several copyright issues, ${ }^{9}$ opposition to the bill focused on digital locks, "fair use and consumer uses of content" (Baird, 2009), issues central to the FCFC movement, rather than, say, rightsholders' needs. In other words, Geist's interventions helped frame copyright as a "user rights" issue. However, Geist had surprisingly little to do with the actual organization of direct protests. While he solicited some individuals to set up their own FCFC chapters across the country, once established they largely made decisions for themselves, including engaging in direct lobbying. Although one activist remarked that "in general ... only a few participants engaged in local face-to-face activities, about one in a hundred" (cited in Smith, 2010), FCFC's large 
number of adherents - over 10,000 by mid-December 2007 and around 41,000 in June 2008 - meant that only a small percentage of them needed to become movement "constituents" in order to have an effect.

The Canadian 2007 Facebook Uprising demonstrates the fundamental point that while social media may widen the scope of political engagement (as would be predicted by RMT: declining organizing costs should lead to greater activism), the effect will depend entirely on the structure of existing political institutions (as PPT would suggest). FCFC brought into being an effective and cohesive, if decentralized, interest group that likely would not have existed in its absence. The increasing exposure of Canadians to online life meant that the number of Canadians using file-sharing technologies such as Napster and BitTorrent, and the related copyright debates, rose throughout the 2000s. Movement entrepreneurs also played a key framing role: Several well-connected (in policy and Internet-network terms) bloggers, particularly Michael Geist, were well positioned to promote this issue to a receptive audience (Smith, 2010), tapping into and channelling pre-existing discontent. Most importantly in the long run, Geist and others were able to maintain a focus on the issue over several years, at least in part because they were able to draw on a solid "real world" institutional base: they had both the time and economic capability to keep the pressure on even beyond the initial burst of support.

The FCFC protests also demonstrated that "Facebook activism" is not a purely decentralized, leaderless phenomenon: it was shaped significantly by those individuals who first started the website. The general philosophy espoused by FCFC groups in large part reflected (although not completely and always) the philosophical (not organizational) influence of Geist in particular, namely his long-standing advocacy for user rights. At the 
same time, Geist and others involved in the FCFC can point to the large number of FCFC members to claim legitimacy for the views he and FCFC have put forward, creating a positive-feedback loop.

FCFC, however, still had to play by the institutional "rules of the game" that constitute politics in Ottawa, rules that concentrate power in the hands of a few people namely, the Prime Minister - and that offer relatively few entry points to influence decisions (White, 2005). Once established, FCFC's ability to shape the copyright agenda was a factor of was when it occurred. Political pressure from individuals (as opposed to pressure from business) works because of the links between political actions and electoral accountability: votes are at stake. In an unreformed, first-past-the-post, centralized Westminster system like Canada's these linkages are quite weak: power is concentrated in the hands of one person, elected indirectly in one riding as the leader of the party and thus the country, typically with a plurality of votes. The disproportionate effect of the Fair Copyright For Canada Facebook group was itself the result of a very unusual confluence of events. It occurred:

- during a minority Parliament;

- at a time when the government was unsure of the strength of the opposition;

- a couple of months before a highly contentious vote on Canada's continued involvement in the war in Afghanistan;

- on an issue that the Conservatives did not think would be politically contentious (that is, they were caught unprepared); and

- through a new communications technology that politicians did not yet know how to interpret. 
Following the Afghanistan vote, the Liberals were revealed to be little more than paper tigers, headed by historically inept leaders who led their party to catastrophic electoral defeats. With an election less of a concern, the Afghanistan issue disposed of and with the separatist Bloc Québécois in favour of stronger copyright legislation and likely to support the Conservatives in the end, the opposition inside and outside of Parliament had little political ammunition to use against the government. In a majority situation, the government - the Prime Minister - could choose to do largely as he wished. Given the governmental position that the Conservatives' copyright bill suffered from bad communication, not bad policy, the introduction of user rights that can be overridden by digital locks was largely a tactical, though not unimportant, concession to a potentially troublesome new interest group. That new user rights emerged at all was largely sue to FCFC pressure.

\section{Conclusion: The contingent effects of online organization}

Social media have been in existence for less than a decade and are likely to become even more prominent in political life. The experience of the Fair Copyright for Canada Facebook group offers a useful case to begin to understand the forces that determine the successes and failures of fully online protests movements. It confirms that digital technologies have changed the resource calculations that determine whether a social movement can come into being, while expanding the types of interests that can be represented in a country's politics.

The FCFC protest established the Canadian user-rights social movement that had building since the early 2000s. Before 2007 - and definitely before 2001 - this perspective was largely absent from the Canadian copyright debate. Going forward, there 
is little question that subsequent copyright reforms will be compelled to address directly this perspective. Its ability to extract policy concessions - public consultations and new (though limited) user rights - was the result of this newly created movement's ability to exploit the resources available to them, namely their vote under a minority government. From a political process perspective, social media do not render obsolete the importance of the "opportunity structure" faced by a social movement. While social media provide new opportunities for the creation of interest groups, these interest groups must still play by existing political rules in the arena of contentious politics. The government's ability to resist the movement's main demand - user-friendly digital-lock rules - was the result of the particular nature of the Canadian political system. The political pressure exerted by the movement could only bring it so far. The Canadian copyright debate thus offers a reminder of the continued salience of political context in considering the effects of online protests: similar protests will have different effects in different regimes.

This is not to minimize the effects of FCFC. Rather, it is to note that its success was contingent not only on how social media function, but also on the overall institutional context in which the policy debate occurred. Those interested in the decentralized-democratic promise of online organization would be well advised to focus significant attention on reforming existing political institutions. The Fair Copyright for Canada case serves as a reminder of the importance of focusing not only on the potential inherent in social-media technologies, but also on the society within which they operate.

\section{ENDNOTES}

${ }^{1}$ The Canadian literature on politics and social media is similarly thin. Notable exceptions include: Small $(2012 ; 2010)$ on governmental and political-party engagement 
with social media; Milner (2010), Bastedo et al. (2012), and Baran (2011) on its effect on participation in electoral politics. For early theoretical discussions on the Internet's effects on civic engagement, see Deibert (2002) and Barney (2003). For an analysis of Canadians' Internet use and civic participation see Veenhof et al. (2008) and Clarke (2012).

${ }^{2}$ Digital locks, or technological protection measures (TPM), are locks applied to digital content to control how a user may use or access the content.

${ }^{3}$ Stop Acta, “INT: Teilnehmerzahlen.” http://wiki.stoppactaprotest.info/INT:Teilnehmerzahlen (May 9, 2013).

4 "Elite interviews" involve interviews with people who have participated in a "certain situations" and involves ascertaining the interviewee's "definition" (or account) of that situation (Kezar, 2003: 397). The goal was a full description and understanding of the Canadian copyright policymaking process from the point of view of those directly involved in it. Some 19 interviews were conducted with Canadian government, industry and civil-society representatives; those directly cited here are listed in the references and the remaining in Haggart (2011a). Interviewees were asked to describe their participation in the Canadian copyright policymaking process and the debate over the Conservative legislation. Reflecting standard snowball-sampling technique (a non-random means to gather relevant interview sources), subjects were also asked to suggest other potentially relevant interviewees.

${ }^{5}$ Even the supposedly leaderless "hactivist" group Anonymous is characterized by a (often-changing) hierarchy that can set strategy and pick targets (Olson, 2012).

${ }^{6}$ The debate is also complicated by the fact that "creators" are also "users": all creation 
builds on what has come before.

${ }^{7}$ According to Austin, Bernier had been shuffled out of the portfolio in part because of a reluctance to implement the type of copyright bill the Prime Minister's Office, on behalf of the United States, had wanted.

${ }^{8}$ Bill C-61 was introduced in June 2008. Bill C-32, now titled the Copyright Modernization Act was introduced in June 2010. Bill C-11, also called the Copyright Modernization Act, was introduced in September 2011 and received Royal Assent on June 29, 2012, seven years after the original Liberal copyright-reform bill. Perhaps the most notable change between the first and second/third Conservative bills is the requirement that damages for non-commercial infringements be proportionate to the infringement (new ss. 38.1(5)(d) in Bill C-32). For a comparison of the 2008 and 2010 bills, see Geist (2010).

${ }^{9}$ See Mahabir and Mingarelli (2008) for a summary of Bill C-61.

\section{REFERENCES}

\section{Interviews by author}

Austin, Michele. April 30, 2008. Chief of Staff, Industry Minister Maxime Bernier.

Geist, Michael. May 14, 2008. Professor of Law, University of Ottawa.

Gratton, Denis. February 7, 2008. Former Manager, Copyright Policy, Department of Canadian Heritage.

Hyndman, Rob. April 22, 2008. Technology lawyer.

Lam, Kempton. April 16, 2008. Copyright blogger.

Mirella, Loris. February 7, 2008. Senior Project Leader, Copyright Policy Branch, Department of Canadian Heritage.

Rioux, Jean-Sébastien. February 26, 2009. Chief of Staff, Industry Minister Jim Prentice. 


\section{Bibliography}

Amnesty International. 2012. "EU urged to reject international anti-counterfeiting pact." February 10. https://www.amnesty.org/en/news/eu-urged-reject-international-anticounterfeiting-pact-2012-02-10 (May 8, 2013).

Badouard, Romain and Laurence Monnoyer-Smith. 2013. "Hyperlinks as Political Resources: The European Commission Confronted with Online Activism." Policy \& Internet 5: 101-117.

Baird, Stacy. 2009. "Contentious Issues: Copyright Reforms in the Age of Digital Technologies." http://papers.ssrn.com/sol3/papers.cfm?abstract id=1520161 (April 22, 2013).

Bannerman, Sara. 2006. "Canadian Copyright Reform: Consulting with Copyright's Changing Public." Intellectual Property Journal 19: 271-97.

Baran, Yaroslav. 2011. "Social Media in Campaign 2011: A Noncanonical Take on the Twitter Effect." Policy Options June-July: 82-85.

Barney, Darin. 2003. "The Morning After: Citizen Engagement in Technological Society." Techné: Research in Philosophy and Technology 11. http://scholar.lib.vt.edu/ejournals/SPT/v9n3/barney.html (May 9, 2013).

Bastedo, Heather et al. 2012. "Youth, Democracy and Civic Engagement: The 'Apathy is Boring' Surveys." Paper presented at the annual meeting of the Canadian Political Science Association, Edmonton.

Bekkers, Victor, Rebecca Moody and Arthur Edwards. 2011. "Micro-mobilization, Social Media and Coping Strategies: Some Dutch Experiences." Policy \& Internet 3: 1-29.

Bennett, W. Lance and Alexandra Segerberg. 2011. "Digital Media and the Personalization of Collective Action." Information, Communication \& Society 14: 770-99.

boyd, danah m. and Nicole B. Ellison. 2009. "Social Network Sites: Definition, History, and Scholarship." Journal of Computer-Mediated Communication 13. http://jcmc.indiana.edu/vol13/issuel/boyd.ellison.html (May 4, 2012).

Business Coalition for Balanced Copyright. 2008. "A Balanced 'Package' Approach for a Strong Canadian Copyright Regime." https://static.googleusercontent.com/external content/untrusted dlcp/services.google.co $\mathrm{m} / \mathrm{en} / / \mathrm{blog}$ resources/google bcbc position paper.pdf (April 22, 2013).

Calderaro, Andrea and Anastasia Kavada. 2013. "Editorial: Challenges and Opportunities of Online Collective Action for Policy Change." Policy \& Internet 5: 1-6. 
Canada. Industry Canada. 2008. "Government of Canada Proposes Update to Copyright Law: Balanced Approach to Truly Benefit Canadians.” June 12. Ottawa: Industry Canada. http://www.ic.gc.ca/eic/site/ic1.nsf/eng/04204.html (June 19, 2010).

Carty, Victoria. 2008. "New Information Communication Technologies and Grassroots Mobilization.” Information, Communication \& Society 13: 155-173.

Cohen, Jodi H. and Jennifer M. Raymond. 2011. "How the Internet is Giving Birth to a New Social Order.” Information, Communication \& Society 16: 937-57.

Clarke, Amanda. 2010. "Social media: 4. Political Uses and Implications for Representative Democracy.” Background Paper No. 2010-10-E. Parliamentary Information and Research Service, Library of Parliament. http://www.parl.gc.ca/Content/LOP/ResearchPublications/2010-10-e.htm (May 9, 2013).

De Beer, Jeremy. 2005. "Constitutional Jurisdiction Over Paracopyright Laws." In In the Public Interest: The Future of Canadian Copyright Law, ed. Michael Geist. Toronto: Irwin Law.

Deibert, Ronald J. 2002. "The Politics of Internet Design: Securing the Foundations for Global Civil Society Networks." http://homes.chass.utoronto.ca/ citizenl/assets/deibert.pdf (May 9, 2013).

Delacourt, Susan. 2008. "Watching for Copyright Reform Reaction.” Susan Delacourt on Politics. June 12. http://thestar.blogs.com/politics/2008/06/watching-for-co.html (May 8, 2013).

Diani, Mario. 2000. "Social Movement Networks Virtual and Real.” Information, Communication \& Society 3: 386-401.

Doern, G. Bruce and Markus Sharaput. 2000. Canadian Intellectual Property: The Politics of Innovating Institutions and Interests. Toronto: University of Toronto Press.

Earl, Jennifer et al. 2010. "Changing the World One Webpage at a Time: Conceptualizing and Explaining Internet Activism." Mobilization: An International Journal 15: 425-46.

Fair Copyright for Canada. 2007. "Fair Copyright: Meeting Jim Prentice, the Minister of Industry.” December 8. http://www.facebook.com/events/7365003311/ (May 18, 2012).

Faris, David. 2008. "Revolutions Without Revolutionaries? Network Theory, Facebook, and the Egyptian Blogosphere." Arab Media \& Society 6. $\mathrm{http}: /$ www.arabmediasociety.com/?article=694 (May 4, 2012).

Gamson, William A. 1990. The Strategy of Social Protest. Homewood: Dorsey.

Garrett, R. Kelly. 2006. "Protest in an Information Society: A Review of Literature on 
Social Movements and ICTs." Information, Communication \& Society 9: 202-224.

Geist, Michael. 2012. "The Battle over C-11 Concludes: How Thousands of Canadians Changed the Copyright Debate," June 18.

http://www.michaelgeist.ca/content/view/6544/125/ (October 30, 2012).

Geist, Michael. 2010. "Comparing the Two Copyright Bills: C-32 vs. C-61," June 4. http://www.michaelgeist.ca/content/view/5088/125/ (June 4, 2012).

Geist, Michael. 2010a. "The Final Copyright Consultation Numbers: No Repeat of Bill C-61.” April 9. http://www.michaelgeist.ca/content/view/4946/125/ (June 5, 2012).

Geist, Michael. 2010b. "The 2009 Copyright Consultation: Setting the Record Straight." April 20. http://www.michaelgeist.ca/content/view/4971/125/ (April 22, 2013).

Geist, Michael. 2008. "Mapping Fair Copyright for Canada.” June 25. http://www.michaelgeist.ca/content/view/3106/99999/ (May 8, 2013).

Geist, Michael. 2008a. "How the U.S. Got its Canadian Copyright Bill." Toronto Star, June 16.

Geist, Michael. 2007. "Copyright's 10k." December 9. http://www.michaelgeist.ca/content/view/2453/125/ (June 4, 2012).

Gladwell, Malcolm. 2010. "Small Change: Why the Revolution Will Not be Tweeted." New Yorker, October 4.

http://www.newyorker.com/reporting/2010/10/04/101004fa_fact_gladwell (May 4, 2012).

Haggart, Blayne. Forthcoming. Copyfight: The Global Politics of Digital Copyright Reform. Toronto: University of Toronto Press.

Haggart, Blayne. 2011. "International Copyright Treaties and Digital Works: Implementation Issues in Canada and Mexico." Australian Journal of Communication 38: 31-46.

Haggart, Blayne. 2011a. "North American Digital Copyright, Regional Governance and the Potential for Variation." Doctoral dissertation. Carleton University, Ottawa, Ontario.

Jensen, Michael J, Laia Jorba and Eva Anduiza. 2012. "The Impact of Digital Media on Citizenship from a Global Perspective." In Digital Media and Political Engagement Worldwide: A Comparative Study, ed. Eva Anduiza, Michael James Jensen and Laia Jorba. Cambridge: Cambridge University Press.

Harlow, Summer and Dustin Harp. 2012. "Collective Action on the Web." Information, Communication \& Society 15: 196-212. 
Karpf, David. 2010. "Online Political Mobilization from the Advocacy Group's Perspective: Looking Beyond Clicktivism.” Policy \& Internet 2: 7-41.

Kezar, Adrianna. 2003. "Transformational Elite Interviews: Principles and Problems." Qualitative Inquiry 9: 395-415.

Lithwick, Dara and Maxime-Olivier Thibodeau. 2011. "Legislative Summary of Bill C11: An Act to Amend the Copyright Act." Ottawa: Library of Parliament. http://www.parl.gc.ca/About/Parliament/LegislativeSummaries/bills 1s.asp?source=librar $\mathrm{y}$ prb\&ls $=\mathrm{C} 11 \&$ Parl $=41 \&$ Ses $=1 \&$ Language $=\mathrm{E} \& M o d e=1$ (May 4, 2012).

Loader, Brian D and Dan Mercea. 2011. "Networking Democracy?” Information, Communication \& Society 14: 757-69.

Loader, Brian D. 2008. "Social Movements and New Media." Sociology Compass 2: $1920-1933$.

Mahabir, Mark and Carolina Mingarelli. 2008. "Bill C-61: An Act to Amend the Copyright Act." LS-613E. Ottawa: Library of Parliament.

Margetts, Helen et al. 2009. "Can the Internet Overcome the Logic of Collective Action? An Experimental Approach to Investigating the Impact of Social Pressure on Political Participation." Paper presented at the annual meeting of the Political Studies Association Annual Conference, Manchester.

Marwell, Gerard and Pamela Oliver. 2008. "The Critical Mass in Collective Action.” In Social Movements: A Reader, ed. Vincenzo Ruggiero and Nicola Montagna. New York: Routledge.

McAdam, Doug. 1982. Political Process and the Development of Black Insurgency, 1930-1970. Chicago: University of Chicago Press.

McAdam, Doug, John D. McCarthy and Mayer N Zald. 1996. "Introduction: Opportunities, Mobilizing Structures and Framing Processes - Toward a Synthetic, Comparative Perspective on Social Movements." In Comparative Perspectives on Social Movements: Political Opportunities, Mobilizing Structures and Cultural Framings, ed. Doug McAdam, John D. McCarthy and Mayer N. Zald. Cambridge: Cambridge University Press.

McCarthy, John D. and Mayer N. Zald. 1977. "Resource Mobilization and Social Movements: A Partial Theory." American Journal of Sociology 82: 1212-1241.

Neumayer, Christina and Celina Raffl. 2008. "Facebook for Global Protest: The Potential and Limits of Social Software for Grassroots Activism." Paper presented at the CIRN Community Informatics Conference, Prato, Italy. pep- 
forums.990086.n3.nabble.com/file/n2539001/2008-Neumayer-Raffl-

Facebook_protest_FARC.pdf(May 4, 2012).

Olson, Parmy. 2012. We Are Anonymous: Inside the Hacker World of LulzSec, Anonymous, and the Global Cyber Insurgency. New York: Little, Brown \& Company.

Oostveen, Anne-Marie. 2010. "Citizens and Activists." Information Communication \& Society 13: 793-819.

Putnam, Robert D. 2000. Bowling Alone: The Collapse and Revival of American Community. New York: Simon \& Schuster.

Rane, Halim and Sumra Salem. 2012. "Social media, social movements and the diffusion of ideas in the Arab uprisings." International Journal of Communication 18: 97-111.

Shulman, Stuart W. 2009. "The Case Against Mass E-mails: Perverse Incentives and Low Quality Public Participation in U.S. Federal Rulemaking." Policy \& Internet 1: 2353.

Sell, Susan K. 2013. "Revenge of the 'Nerds': Collective Action against Intellectual Property Maximalism in the Global Information Age." International Studies Review 15: 67-85.

Shirky, Clay. 2011. "The Political Power of Social Media: Technology, the Public Sphere, and Political Change." Foreign Affairs January/February.

http://www.foreignaffairs.com/articles/67038/clay-shirky/the-political-power-of-socialmedia (May 4, 2012).

Small,Tamara. 2012. "E-Government in the Age of Social Media: An Analysis of the Canadian Government's Use of Twitter." Policy \& Internet 4: 91-111.

Small, Tamara. 2010. "Canadian Politics in 140 Characters: Party Politics in the Twitterverse." Canadian Parliamentary Review Autumn: 39-45.

Smith, Peter (Jay). 2010. "Social Networking and Political Activism ... More Orchestrated Campaigns or Just Karaoke?" Paper presented at the annual meeting of the International Studies Association, New Orleans. http://citation.allacademic.com//meta/p mla apa research citation/4/1/5/7/7/pages41577 1/p415771-1.php (April 22, 2013).

Tarrow, Sidney. 2011. Power in Movement: Social Moments, Collective Action and Politics. $3^{\text {rd }}$ ed. Cambridge: Cambridge University Press.

Tilly, Charles. 2003. "Social Movements Enter the Twenty-first Century." Paper presented at the conference on Contentious Politics and the Economic Opportunity Structure: Mediterranean Perspectives, Rethimno, Greece. 
http://falcon.arts.cornell.edu/sgt2/PSCP/documents/tilly2003-03.pdf (April 30, 2013).

Veenhof, Ben et al. 2008. "How Canadians' Use of the Internet Affects Social Life and Civic Participation." Statistics Canada Research Paper n. 56F004M - no. 016. Ottawa: Statistics Canada. http://www.statcan.gc.ca/pub/56f0004m/56f0004m2008016-eng.pdf (May 9, 2013).

White, Graham. 2005. Cabinet and First Ministers. Vancouver: University of British Columbia Press. 